\title{
Constraints of paddy production in Western Terai of Nepal
}

\section{Chetana Basyal*, Sarthak Ghimire, Bipin Panthi and Sudarshan Basyal}

Institute of Agricultural Sciences, Banaras Hindu University, Varanasi, U.P., India

*corresponding author: 12chetana28@gmail.com

\begin{abstract}
Paddy is important crop of Nepal, which have significant role in food security and supporting livelihood of the Nepalese population. Although Nepal has harvested the record production in recent year, but it is still far behind to substitute the import. Various strategies are required to be developed to make Nepal self-sufficient in rice. The objective of this paper is to identify the various constraints of paddy production in Nepal. This study utilizes the primary data collected through semi-structured questionnaires. A total 120 paddy growing household were surveyed in Kapilvastu and Rupandehi district (60 in each district) for the study. Study identifies, that among the various constraints faced by farmers major constraints are lack of improved varieties, inadequate supply of chemical fertilizer, lack of proper farm equipment and dependence on monsoon rain for successful crop.
\end{abstract}

Keyword-Paddy, Agricultural Constraints, Food security, Western Terai.

\section{INTRODUCTION}

Nepalese economy heavily depends upon agriculture, which contributes 27.1 per cent of the total GDPand provides livelihood to 65.6per cent of Nepalese population (MoALD, 2019). Among the various crops grown, Paddy is the most important staple crop of Nepal. It holds first rank in term of livelihood generation, area and production (Gauchan et al., 2012; MOAD, 2017). It is grown in about half of net cultivated area of Nepal and contributes about $20 \%$ of the total Agricultural GDP (Gauchan et al., 2014). It supplies about $40 \%$ of total calories intake of Nepalese people. Hence, it can be said thatpaddy has significant role in food security and supporting livelihood of Nepalese people.

In Nepal, paddy is grown in varying agro-ecological conditions ranging from 50 to 3000 meter above sea level (Gauchan et al., 2014). Among the total production, about two-thirds of them are produced in southern plain. Due to the lack of all-year-round irrigation facilities, majority of the paddyproduced in the country is rain-fed (Tripathi et al., 2012). Success of paddy production depends upon monsoon rains in Nepal. Although Nepal has harvested the highest paddy production in the recent year, but still it was not able to substitute the import from other countries (Prasain, 2018). There exists lots of challenges in improving production of paddy in Nepal. Therefore, this study was carried to identify the constraints of paddy production in Nepal.

\section{RESEARCH METHODOLOGY}

This study was conducted in western Terai of Nepal. Kapilvastu and Rupandehi districts was purposively selected for the study because of their high potential for paddy production. This study utilizes primary data to fulfil its research objective. Primary data was collected by using semistructured questionnaire. A total of 120 paddy growing families were selected for the study (60 from each district) in the month of September and October 2018, through simple random sampling method. Data was collected about their socioeconomic characteristics and the constraints they are facing in paddy production. Socioeconomic characteristics included gender of head of farming household, age, family size, education and landholding. To work out the constraints faced by the farmers in paddy production, constraints were characterized into four groups viz. agro-ecological, economic, technical and institutional constraints, which were listed out by key informant interview and group discussion. The raw data collected were coded and entered into computer for analysis. They were analyzed using M.S Excel and SPSS v25.0. Socioeconomic characteristics of farmers were presented using descriptive statistics like mean, frequency and percentage. And, constraints were ranked based on the percentage of farmers reporting it. 


\section{RESULT AND DISCUSSION}

\section{a. Socioeconomic characteristics}

We need to scrutinize the socioeconomic characteristics of the studied population in order to have clear understanding of constraints perceived by them. The socioeconomic characteristics of the respondents are presented in Table 1.

It was found that males holding the position of head in farming household is much more than the female holding the similar position. Male holds position of head in $80 \%$ of the studied area, compared to female in only $20 \%$. This situation can be taken as a remnant of patriarchal nature of ancient agriculture (FAO, 2019). According to the age, active population (15-64 years old) represented $89.17 \%$ of the total studied population. Only $10.83 \%$ of the population were inactive population $(64+$ years old $)$.

For this study, farming households were classified into three categories based on the family size viz. small (050), medium (5-10) and large (>10). It was found that majority of the farmers belongs to medium category (65.83\%), followed by small (27.50) and large (6.67\%), respectively.
In term of education, it was found that majority of the farming household are medium-sized $(65.83 \%)$, followed by small $(27.50 \%)$ and large size $(6.67 \%)$. Majority of farmers are educated up to secondary level $(35.83 \%)$, followed by primary level $(30.83 \%)$ and university level $(20.00 \%) .13 .33 \%$ of the total studied population never attended any institution for education.

Farming household were categorized based on their size of total land holding: below $0.5 \mathrm{Ha}$ as a marginal farmer, 0.5 to $2 \mathrm{Ha}$ as a small farmer and above $2 \mathrm{Ha}$ as a large farmers. Table shows that majority of total studied farming household are small constituting $54.16 \%$ of total studied household. $35.00 \%$ of farmers are marginal, and $10.83 \%$ are large farming household, average farm size being $0.98 \mathrm{Ha}$, which is higher than average farm size of $0.8 \mathrm{Ha}$ (CBS, 2011). Study shows that $48.33 \%$ farming household have operational land under agriculture in between $0.5-2 \mathrm{Ha}$, followed by $45.83 \%$ and $5.83 \%$ farming household with operational land below $0.5 \mathrm{Ha}$ and above $2 \mathrm{Ha}$, respectively. The average operational area was $0.92 \mathrm{Ha}$, and average paddy cultivated area was 0.72 ha.

Table 1: Socioeconomic characteristics of the respondents.

\begin{tabular}{|c|c|c|c|}
\hline Characteristics & Variables & Frequency & Percentage \\
\hline \multirow{2}{*}{$\begin{array}{l}\text { Sex of Head of Farming } \\
\text { household }\end{array}$} & Female & 24 & 20.00 \\
\hline & Male & 96 & 80.00 \\
\hline \multirow[t]{2}{*}{ Age } & Active population $(15-64)$ & 107 & 89.17 \\
\hline & Inactive population $(0-14 \& 65+)$ & 13 & 10.83 \\
\hline \multirow[t]{3}{*}{ Household size } & Small (0-5) & 33 & 27.50 \\
\hline & Medium (5-10) & 79 & 65.83 \\
\hline & Large $(>10)$ & 8 & 6.67 \\
\hline \multirow[t]{4}{*}{ Education } & Illiterate & 16 & 13.33 \\
\hline & Primary level & 37 & 30.83 \\
\hline & Secondary level & 43 & 35.83 \\
\hline & University level & 24 & 20.00 \\
\hline \multirow[t]{4}{*}{ Total Land holding } & Marginal $(<0.5 \mathrm{Ha})$ & 42 & 35.00 \\
\hline & Small (0.5 - 2 Ha) & 65 & 54.16 \\
\hline & Large $(>2 \mathrm{Ha})$ & 13 & 10.83 \\
\hline & Average farm size & \multicolumn{2}{|c|}{$0.98 \mathrm{Ha}$} \\
\hline \multirow[t]{5}{*}{ Operational land holding } & $<0.5 \mathrm{Ha}$ & 55 & 45.83 \\
\hline & $0.5-2 \mathrm{Ha}$ & 58 & 48.33 \\
\hline & $>2 \mathrm{Ha}$ & 7 & 5.83 \\
\hline & Average operational land & \multicolumn{2}{|c|}{$0.92 \mathrm{Ha}$} \\
\hline & Average paddy cultivated area & \multicolumn{2}{|c|}{$0.72 \mathrm{Ha}$} \\
\hline
\end{tabular}




\section{b. Constraints of paddy production as perceived by farmer}

The constraints of paddy production perceived by the farmers are categorized into 4 different categories, i.e. agro ecological, economical, technical and institutional.
Farmers were asked what are the constraints in paddy production and these constraints were ranked based on the frequency they are reported. Constraints perceived by the farmers are presented in Table 2 .

Table 2: Constraints of paddy production as perceived by farmers

\begin{tabular}{|c|c|c|c|c|}
\hline S.N & Constraints & Frequency & Percentage & Rank \\
\hline $\mathbf{A}$ & \multicolumn{4}{|l|}{ Agro-Ecological } \\
\hline & 1. Late Commencement of rainfall & 98 & 81.67 & I \\
\hline & 2. Soil problems & 85 & 75.83 & II \\
\hline & 3. $\quad$ Rainfall Pattern & 69 & 57.50 & III \\
\hline & 4. Early cessation of rainfall & 42 & 35.00 & IV \\
\hline & 5. Topography & 8 & 6.67 & $\mathrm{~V}$ \\
\hline \multirow[t]{11}{*}{$\mathbf{B}$} & \multicolumn{4}{|l|}{ Economic } \\
\hline & 1. Chemical Fertilizer & 102 & 85.00 & I \\
\hline & 2. $\quad$ Farm Equipment & 97 & 80.83 & II \\
\hline & 3. Improved Seed & 95 & 79.17 & III \\
\hline & 4. $\quad$ Labour wage & 63 & 52.50 & IV \\
\hline & 5. Electricity Charge & 24 & 20.00 & IX \\
\hline & 6. FYM & 57 & 47.50 & $\mathrm{~V}$ \\
\hline & 7. Pesticide & 46 & 38.33 & VI \\
\hline & 8. Land Distribution & 38 & 31.67 & VII \\
\hline & 9. Water cost & 27 & 22.50 & VIII \\
\hline & 10. Transportation fee & 5 & 4.17 & $\mathrm{X}$ \\
\hline \multirow[t]{11}{*}{$\mathbf{C}$} & \multicolumn{4}{|l|}{ Technical } \\
\hline & 1. Lack of Improved varieties & 106 & 88.33 & I \\
\hline & $\begin{array}{l}\text { 2. Unavailability of quality } \\
\text { insecticide/pesticide }\end{array}$ & 65 & 54.16 & II \\
\hline & 3. Lack of proper irrigation system & 64 & 53.33 & III \\
\hline & $\begin{array}{l}\text { 4. Lack of modern farm machineries } \\
\text { like sprayer, harvester, thrasher, } \\
\text { etc. }\end{array}$ & 61 & 50.83 & IV \\
\hline & 5. $\quad$ Post-harvest technology & 28 & 23.33 & IX \\
\hline & 6. Lack of agricultural labourer & 54 & 45.00 & $\mathrm{~V}$ \\
\hline & 7. Heavy pest and weed Infestation & 51 & 42.50 & VI \\
\hline & 8. $\quad$ Occurrence of new paddy disease & 51 & 42.50 & VI \\
\hline & 9. $\mathrm{FYM}$ & 43 & 35.83 & VIII \\
\hline & 10. Intensive Field preparation & 19 & 15.83 & $\mathrm{X}$ \\
\hline $\mathbf{D}$ & \multicolumn{4}{|l|}{ Institutional } \\
\hline & 1. $\quad$ Training & 72 & 60.00 & $\mathrm{I}$ \\
\hline & 2. $\quad$ Proper market & 72 & 60.00 & $\mathrm{I}$ \\
\hline & 3. Extension Services & 66 & 55.00 & III \\
\hline
\end{tabular}




\begin{tabular}{|c|c|c|c|c|}
\hline & 4. Weather Information & 61 & 50.83 & IV \\
\hline & 5. Poor Infrastructure & 25 & 20.83 & IX \\
\hline & 6. Crop Insurance & 54 & 45.00 & V \\
\hline & 7. Market Information & 46 & 38.33 & VI \\
\hline & 8. Electricity and fuel & 46 & 38.33 & VI \\
\hline & 9. Proper Credit & 36 & 30.00 & VIII \\
\hline & 10. Access to market & 21 & 17.50 & $\mathrm{X}$ \\
\hline
\end{tabular}

\section{Agro ecological constraints}

It is found that late commencement of rainfall in paddy growing season was perceived by majority of farmer as constraint related to agro ecological condition in the studied area. Farmers in the studied area grow paddy crop in the monsoon season, and commencement of monsoon is marks starting of sowing/transplanting crop. Late starting of monsoon has delayed their cropping time. Similarly, soil problem is perceived as the second constraint in the total studied population. Farmers reveled that decrease in the soil fertility is prevalent in the paddy growing fields in both the districts, which has forced them to have reduced productivity. Rainfall pattern and early cessation of rainfall were perceived as third and fourth constraint respectively. These two constraint along with late commencement of rains, can be related to the climate change (Kang et al., 2009). As the studied area is located in the plain topography which is most suitable for lowland paddycultivation, topography is the least perceived constraint, perceived by only $6.67 \%$ of respondent.

\section{Economic Constraints}

Most important constraint perceived by the farmers in the area is high cost of chemical fertilizer, which is perceived by the $85.00 \%$ of the total respondent. Farmers revealed that high cost of primary fertilizer like Urea, DAP, MOP, etc. and micronutrient has left them incapable of using recommended dose of chemical fertilizer. It is also reported that in recent years Nepalese farmers are facing lack of chemical fertilizer in market, and often they pay high prices while buying from black market (Acharya, 2019). Similarly, high cost of the farm equipment is perceived as the second most important constraint by the farmers, which is perceived by $80.83 \%$ of total respondent. Paddycultivation requires intensive use of farm machinery from preliminary land preparation to thrashing. This could be the reason for lack of proper mechanization in Nepal (Shrestha, 2012). High cost of improved seed is third most important constraint in paddy production in the total studied population, which is perceived by $79.17 \%$ of respondent.
Labour wage is another important constraint of the studied population, which is perceived by $52.50 \%$ of respondent. Availability of the fully decomposed FYM is another important constraint of the paddyproduction, perceived by $47.50 \%$ of the farmers. High cost of pesticide is the sixth important constraint, perceived by $38.33 \%$ of the respondents. Other constraints perceived by the farmers are land distribution, high water cost, high electricity charges and high transportation charges, which is perceived by $31.67 \%, 22.50 \%, 20.00 \%$ and $4.17 \%$ of the total respondents, respectively.

\section{Technical Constraints}

Lack of improved varieties is the most important constraints as perceived by the farmers, which is perceived by $88.33 \%$ of respondents. Although various initiatives are being done in Nepal for improvement of rice varieties, still very less success is achieved (Ghimire et al., 2015). Similarly, Unavailability of the quality insecticide/ pesticide is second most important technological constraint, which is perceived by $54.16 \%$ of the respondents. Similarly, lack of proper irrigation system is identified as the third most important technological constraint which is perceived by $53.33 \%$ of the total respondent. Lack of modern farm machineries is the fourth most important technological constraints, which is perceived by $50.83 \%$ of the total respondent. Lack of agricultural labourer is the fifth important constraint, which is perceived by $45.00 \%$ of the respondents. Heavy pest and weed infestation and occurrence of disease is perceived another important technological constraint, which is perceived by $42.50 \%$ respondents. Other technological constraints are unavailability of the farmyard manure, post-harvest technology and intensive land preparation, which is perceived by $35.83 \%, 23.33 \%$ and $15.83 \%$ of the total respondents, respectively.

\section{Institutional Constraints}

Poor market infrastructure and lack of training is the most important institutional constraints which is 
perceived by $60.00 \%$ of the total respondents. Another important institutional constraint is lack of extension services in the studied area, which is perceived by $55.00 \%$ of the total respondents. Similarly, $50.83 \%$ of farmers reported that they do not have proper information related to weather. This supports the above-mentioned rainfall related constraints in agro ecological category. Other constraints perceived by farmers include lack of proper crop insurance policies (45\%), lack of access to market information $(38.33 \%)$, unavailability of sufficient electricity and fuel (38.33\%) for irrigation and mechanization, lack of access to credit $(30.00 \%)$, poor infrastructure $(20.83 \%)$ and access to market $(17.50 \%)$.

\section{CONCLUSION}

This study explores the various constraints faced by the paddy farmers in the western Terai of Nepal, which have great potential of paddyproduction because of climate and geographical suitability. Study identifies, that among the various constraints faced by farmers major constraints are lack of improved varieties, inadequate supply of chemical fertilizer, lack of proper farm equipment and dependence on monsoon rain for successful crop. These findings calls for the governmental bodies, research institutions, local agencies and other stakeholders to design plan and implement a proper strategy to increase the paddy productivity in the area, and support the livelihood and food security in the region.

\section{REFERENCES}

[1] Acharya, S. (2019). Farmers face shortage of chemical fertiliser. Kathmandu Post. Retrieved from https://kathmandupost.com/money/2019/01/26/farmers-faceshortage-of-chemical-fertiliser

[2] CBS. (2011). National Population and Housing Census 2011. National Planning Comission Secretariat, Government of Nepal: Singhdurbar,Kathmandu, Nepal.

[3] FAO. (2019). Country gender assessment of agriculture and the rural sector in Nepal. Kathmandu.

[4] Gauchan, D., Panta, H. K., Gautam, S., \& Nepali, M. B. (2012). Patterns of adoption of improved rice varieties and farm-level impacts in stress-prone rainfed areas of Nepal. In S. Pandey, D. Gauchan, M. Malabayabas, M. Bool-Emerick, \& B. Hardy (Eds.), Patterns of adoption of improved rice varieties and farm-level impacts in stress-prone rainfed areas in south Asia (pp. 37-103). International Rice Research Institute. Retrieved from https://ideas.repec.org/b/ags/irricg/164467.html

[5] Gauchan, D., Sapkota, B., Gautam, S., Magar, D. B. T., Sharma, B., Amatya, S., Sapkota, S., Nepali, M.B., Singh, S.
\&Singh, U. S. (2014). Development and Dissemination of Stress-tolerant Rice Varieties in Nepal. Nepal Agricultural Research Council, Lalitpur, Nepal.

[6] Ghimire, R., Wen-chi, H., \& Shrestha, R. B. (2015). Factors affecting adoption of improved rice varieties among rural farm households in Central Nepal. Rice Science, 22(1), 3543. https://doi.org/10.1016/S1672-6308(14)60278-X

[7] Kang, Y., Khan, S., \& Ma, X. (2009). Climate change impacts on crop yield, crop water productivity and food security - A review. Progress in Natural Science, 19(12), 1665-1674. https://doi.org/10.1016/j.pnsc.2009.08.001

[8] MOAD. (2017). Statistical information on Nepalese agriculture 2016/17. Ministry of Agricultural Development, Singha Durbar, Kathmandu.

[9] MoALD. (2019). Krishi Diary "In Nepali." Hariharbhawan, Lalitpur, Nepal: Agricultural Information and Training Centre, Ministry of Agriculture and Livestock Development.

[10] Prasain, S. (2018). Nepal poised to harvest largest ever paddy crop. Kathmandu Post. Retrieved from https://kathmandupost.com/money/2018/10/29/nepal-poisedto-harvest-largest-ever-paddy-crop

[11] Shrestha, S. (2012). Status of Agricultural Mechanization in Nepal.

[12] Tripathi, B. P., Mahato, R. K., Yadaw, R. B., Sah, S. N., \& Adhikari, B. B. (2012). Adapting Rice Technologies to Climate Change. Hydro Nepal: Journal of Water, Energy and Environment, 69-72. https://doi.org/10.3126/hn.v11i1.7209 